\title{
PENGEMBANGAN PENGETAHUAN PENGELOLAAN SAMPAH PADA ANAK-ANAK DAN REMAJA DI LINGKUNGAN JORONG LOMBOK TIMUR
}

\author{
Islamul Hadi ${ }^{1}$, I Wayan Suana ${ }^{1}$, Aida Muspiah¹, Faturrahman¹, Yuliadi Zamroni ${ }^{1}$ \\ ${ }^{1}$ Program Studi Biologi FMIPA Universitas Mataram \\ *Co-Author : islamulh@unram.ac.id @unram.ac.id
}

\begin{abstract}
ABSTRAK. Lingkungan Jorong merupakan lingkungan Kelurahan Kelayu Jorong merupakan salah satu kelurahan Kota Selong dengan jumlah penduduk sekitar 2000 jiwa. Sebagian besar penduduk di lingkungan Jorong profesi sebagai petani. Kondisi ini menyebabkan Lingkungan Jorong sangat potensial sebagai penghasil sampah baik sampah dari hasil pertanian dan peternakan, sampah rumah tangga maupun sampah lainnya. Saat ini di lingkungan Jorong berkembang wisata aquatik berupa kolam pemandian yang mulai ramai dikunjungi oleh masyarakat dari luar Kelurahan Kelayu Jorong. Hal ini sangat potensial menghasilkan sampah organik maupun non-organik dari makanan yang dikonsumsi oleh pengunjung. Kegiatan Pengabdian pada Masyarakat ini dilaksanakan di areal Perguruan NW Jorong yang meliputi Madarasah Tsanawiyah (MTs) dan Madrasah Ibtidaiyah (MI). Kegiatan ini telah dilaksanakan pada bulan November 2018. Dalam kegiatan ini telah dilakukan pendekatan yaitu ceramah dan pemutaran audio visual tentang manajemen pengelolaan sampah yang meliputi pengetahuan jenis-jenis sampah, akibat-akibat yang ditimbulkan oleh sampah, metode pembuangan sampah, serta pengolahan sederhana sampah menjadi produk yang bisa dimanfaatkan. Selain itu telah dilaksanakan demonstrasi yang meliputi desain penampung sampah berdasarkan jenisnya dan tata laksana pengumpulan sampah, serta pengolahan samapah sederhana menjadi produk yang bisa dimanfaatkan. Terbatasnya waktu serta kondisi lingkungan yang tidak memungkinkan akibat bencana alam gempa yang menimpa pulau Lombok akhir Juli-September 2018 menyebabkan tidak semua target kegiatan terpenuhi terutama pada fase pemanfaatan sampah organik dan uji coba penggunaaan produk pupuk organic untuk penanaman sayur organik.
\end{abstract}

Kata Kunci: sampah, organik, anorganik, remaja, Kelayu Jorong

ABSTRACT. Jorong is an environment of Kelayu Village Jorong is one of the villages of Selong City with a population of around 2000 people. Most of the population in Jorong are professionals as farmers. This condition causes Jorong Environment to be very potential as a producer of waste both from agricultural and animal husbandry, household waste and other rubbish. Currently in the Jorong environment developing aquatic tourism in the form of a bathing pool that began to be visited by people from outside Kelayu Jorong. This has the potential to produce organic and non-organic waste from food consumed by visitors. Community Service Activities are carried out in the NW Jorong Education Area which includes Madarasah Tsanawiyah (MTs) and Madrasah Ibtidaiyah (MI). This activity was carried out in November 2018. In this activity an approach has been carried out namely lectures and audio-visual playback of waste management which includes knowledge of the types of waste, the effects caused by garbage, methods of disposal of waste, and simple processing of waste into products that can be utilized. In addition, demonstrations have been carried out, which include the design of waste collection based on its type and the procedure for collecting waste, 
as well as processing simple waste into products that can be utilized. The limited time and environmental conditions that were not possible due to the natural disaster of the earthquake that struck the island of Lombok late July-September 2018 caused not all of the target activities to be met, especially in the phase of utilizing organic waste and testing the use of organic fertilizer products for growing organic vegetables.

Keywords: garbage, organic, inorganic, adolescent, Kelayu Jorong

\section{PENDAHULUAN}

Kelurahan Kelayu Jorong merupakan salah satu keluarahan di wilayah Kota Selong Kabupaten Lombok Timur. Kelurahan ini memiliki luas $3.3 \mathrm{~km}^{2}$ dengan jumlah penduduk 5208 jiwa atau setara dengan 1328 kepala keluarga (KK) dan kepadatan 1552 jiwa/ $\mathrm{km}^{2}$ (BPS,2016). Kepadatan penduduk yang tinggi akan berakibat linear dengan produksi barang sisa konsumsi yang didefiniskan sebagai sampah menurut UU No.18 tahun 2008 (Lembaran Negara RI No.4581, 2008 ).

Secara demografi, penduduk Lingkungan Jorong sebagian besar berprofesi sebagai petani yang sekaligus sebagai peternak dengan berbagai jenis ternak. Hal ini tentu akan menghasilkan sampah terutama sampah organik sisa kegiatan pertanian dan juga peternakan serta limbah organik rumah tangga yang belum dimanfaatkan secara optimal.

Saat ini, Kelurahan Kelayu Jorong juga mengembangkan wista aquatik berupa kolam pemandian. Hal ini merupakan daya tarik yang mengundang masyarakat dari luar Kelayu Jorong untuk berkunjung menikmati atraksi wisata yang ada. Akibatnya terjadi penambahan volume sampah yang dibawa oleh pengunjung. Selain itu, keberadaan wilayah Kelayu Jorong sebagai lintasan badan air untuk irigasi Kokoq Aik Ampat dan Kokoq Tojang sering kali menjadi lokasi penumpukan sampah baik oeganik dan non-organik yang berasal dari daerah di sebelah barat Kelayu Jorong.

Dari kondisi yang diuraikan di atas, Kelayu Jorong merupakan wilayah yang memiliki potensi pemanfaatan sampah terutama sampah organik. Hal ini merupakan peluang bagi remaja Lingkungan Jorong untuk bisa menciptakan peluang potensi ekonomi baru yang dapat meningkatkan taraf hidup masyarakat khususnya remaja. Secara umum, pemanfaatan sampah ini juga akan membantu meningkatkan sanitasi lingkungan. Lebih jauh, sampah organik yang seyogyanya bisa dimanfaatkan sebagai pupuk kompos untuk budidaya sayur mayur sebagai salah satu bahan konsumsi masyarakat di Kelayu Jorong dan masyarakat di sekitar Kota Selong. Pembudidayaan sayur mayur secara organik dengan memanfaatkan pupuk kompos hasil olahan sampah organik, akan meningkatkan derajat kesehatan masyarakat, menjadi sumber mata pencaharian alternatif, serta bisa dikembangkan sebagai wisata agro.

\section{ANALISIS PERMASALAHAN}

Berdasarkan analisis situasi tersebut, maka dapat dirumuskan permasalahan prioritas yang harus diselesaikan dalam upaya pengelolaan sampah secara terpadu di Lingkungan Jorong, antara lain:

1. Desain alat pengumpul sampah berdasarkan jenis sampah.

2. Pengolahan sampah organik menjadi pupuk kompos 
3. Demonstrasi plot (demplot) pembudidayaan sayur mayur secara organik

\section{Tujuan dan Manfaat}

Kegiatan ini bertujuan untuk memberikan pengetahuan praktis bagi para remaja di Lingkungan Jorong untuk dapat memanfaatkan sampah organik sebagai bahan baku pebuatan pupuk untuk budidaya pertanian organik.

\section{METODE PELAKSANAAN}

Permasalahan yang dihadapi oleh Kelurahan Kelayu Jorong dalam upaya pengelolaan sampah secara terpadu, akan dipecahkan dengan beberapa pendekatan, antara lain:

1. Visualisasi dan Ceramah tentang Sampah dari berbagai sudut pandang dan pengetahuan. Pada kegiatan ini akan dilakukan pemutaran atau presentasi materi jenis-jenis sampah, akibat pembuangan sampah sembarangan, memilah sampah berdasakan jenis sampah, manfaat sampah, pengelolaan sampah organic. Pada kegiatan, ceramah dan visualisasi materi ceramah menggunakan media audio visual seperti LCD Projector, poster, spanduk, banner, pemutaran film

2. Desain alat pengumpulan sampah (bak sampah) berdasarkan jenis sampah yang akan dibuang. Desain ini lebih kepada menempatkan bak sampah sebanyak jenis sampah yang akan dikoleksi. Bak-bak sampah tersebut dilabel sesuai jenis sampah untuk memberikan petunjuk kepada para siswa, guru, tenaga administrasi maupun masyarakat untuk membuang sampah ke bak sampah yang tepat sesuai dengan jenis sampahnya. Pada kegiatan ini, bak sampah akan diletakkan berpasangan di depan kelas dengan label "SAMPAH ORGANIK" dan "SAMPAH ANORGANIK"

3. Pengolahan sampah organik menjadi pupuk kompos dengan metode kompos aerob (Yuniawati et.al, 2012) dan juga Takakura ( Suana et al. 2016).

Metode aerob merupakan salah satu metode pembuatan kompos yang memiliki beberapa kelebihan, diantaranya: pembuatannya gampang, praktis, murah dan tidak berbau. Bahanbahannya berasal dari sampah organik rumah tangga,pertanian dan peternakan. Aktivatornya merupakan mikroorganisme yang dapat dibeli secara komersil di toko-toko pertanian misalnya EM4.

4. Demplot pembudidayaan sayur mayur secara organik yang bisa dipanen setiap hari

Tujuan kegiatan ini adalah mendemonstrasikan pembudidayaan sayur mayur secara organik. Sayuran yang akan ditanam adalah pakcoy (sawi mangkok) dan kangkung, karena merupakan sayur yang banyak dikonsumsi oleh masyarakat Kelayu jorong. Di samping itu, sawi mangkok dan kangkung memiliki usia panen $( \pm 40$ hari).

Pembudidayaan sawi mangkok dan kangkung akan dibuat sedemikian rupa sehingga bisa dipanen setiap hari. Karena umur sawi mangkok dan kangkung adalah \pm 40 hari, maka akan dibuat bedengan sebanyak 10 , dengan ukuran bedengan masing-masing $1 \mathrm{~m} \times 10 \mathrm{~m}$. Masingmasing bedengan akan ditanami sawi mangkok dengan selang waktu 4 hari dengan harapan dapat dipanen secara bergilir dan terus-menerus. Pembudidayaan sawi hijau dilakukan secara organik dengan memanfaatkan pupuk kompos hasil pengolahan sampah organik. 


\section{HASIL DAN PEMBAHASAN}

\section{Kegiatan Visualisasi dan Ceramah}

Kegiatan ini telah dilaksanakan pada tanggal 3 dan 10 November 2018. Kegiatan ini dilaksanakan di musholla perguruan NW Jorong, Kelurahan Kelayu Jorong, Lombok Timur. Pada kegiatan ini dihadiri oleh para siswa MTs dan MI NW Jorong, alumni MTS NW Jorong, para guru dan staf administrasi, pengurus Yayasan Tadrisul Ummah NW Jorong, serta Komite Madrasah NW Jorong. Kegaiatan ini dilaksanakan dengan memvisualisasikan materi dalam bentuk poster, ceramah, diskusi tentang materi yang berkaitan dengan kegiatan pengabdian ini (gambar1.). Materi ceramah dalam bentuk poster disajikan dalam lampiran laporan ini.
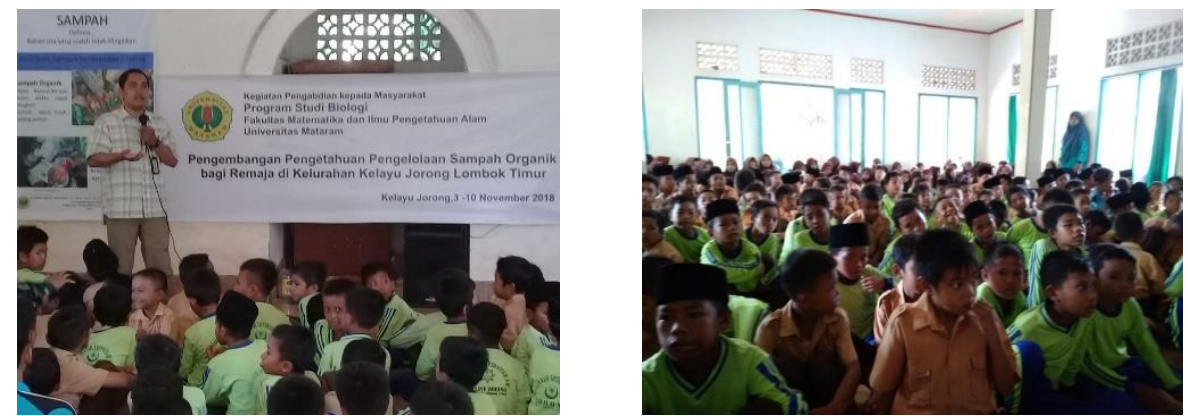

Gambar 1. Ceramah tentang sampah dan pengelolaannya di depan siswa-siswi, guru-guru, staf admnistrasi MTs dan Ml Jorong Kelayu Jorong.

Untuk menindaklanjuti kegiatan ceramah ini, dalaksanakan penyerahan peralatan pengumpul sampah berupa bak sampah sebanyak 9 unit dengan rincian 4 unit untuk Madrasah Tsanwiyah (MTs) dan 5 unit untuk Madrasah Ibtidaiyah. Bak sampah tersebut ditempatkan di selasar depan ruang kelas secara berganda dengan label "Sampah Organik" dan "Sampah Anorganik" (gambar 2). Pengadaan bak sampah ini diharapkan dapat mempermudah siswa, guru, teanga administrasi menyimpan sampah berdasarkan jenis sampah yang akan disimpan.

Penggunaan bak sampah ini perlu dimonitor dalam jangka panjang untuk mengetahui apakah penggunaan sudah sesuai dengan peruntukan. Selain itu, jika ada masalah dalam pemanfaatan yang tidak sesuai peruntukan, perlu dilakukan evaluasi sebagai dasar dari pembuatan solusi yang diperlukan.

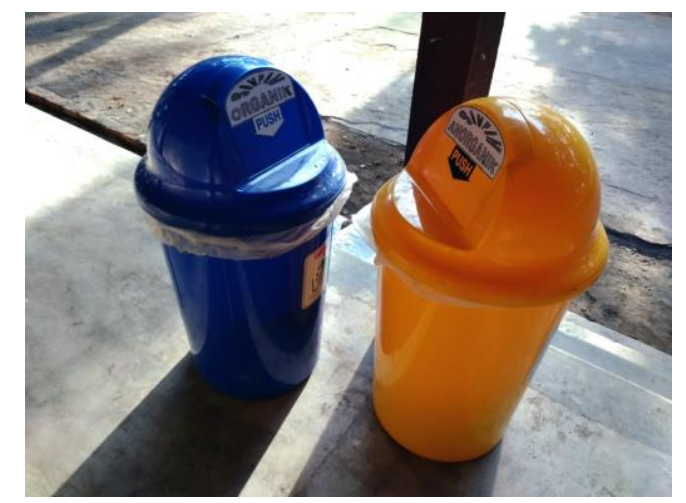

Gambar 2. Bak sampah untuk Madrasah Tsanwiyah \& Madrasah Ibtidaiyah 
Kegiatan selanjutnya yang diharapkan adalah pengumpulan sampah yang telah dipilah. Sampah dari bak sampah organic diharapkan dapat dimanfaatkan untuk pembuatan pupuk organik dengan metode sederhana. Sampah anorganik yang terkumpul diharapkan dapat dimanfaatkan untuk kerajinan tangan atau diserahkan kepada pengepul sampah anorganik sehingga tidak menumpuk di lingkungan madrasah.

Kegiatan pengabdian pada masyarakat (PPM) saat ini baru sampai pada tahap pengembanagan pengetahuan untuk memilah sampah. Hal ini disebabkan karena terbatasnya waktu pelaksanaan kegiatan dan berubahanya khalayak target kegiatan pegabdian. Ini dikarenakan situasi bencana alam gempa bumi yang menimpa Pulau Lombok dan Sumbawa pada bulan JuliSeptember 2018. Kelompok remaja yang merupakan target awal juga sudah mulai tidak aktif karena sebagian besar anggotanya sudah mendapatkan pekerjaan di luar wilayah Kelurahan Kelayu Jorong. Pemilihan target sasaran pengganti yaitu siswa-siswi Madrasah Tsanwiyah (MTs) dan Madrasah Ibditaiyah (MI) karena mereka adalah kelompok masyarakat yang sangat potensial dalam belajar mengelola sampah melalui perubahan pola pikir baik secara kurikuler maupun ekstrakurikuler.

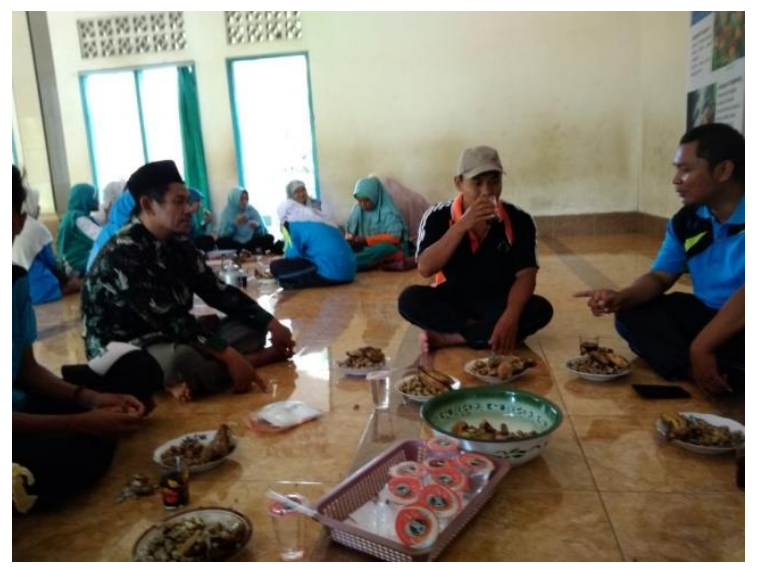

Gambar 3. Diskusi tentang sampah dan pengelolaannya dengan para remaja dan guru- guru, staf admnistrasi MTs dan MI Jorong Kelayu Jorong.

Kegiatan ini dianggap cukup berhasil dengan antusiasme khalayak sasaran kegiatan ini yang cukup banyak. Selain itu, dukungan institusi madrasah maupun yayasan Tadrisul Ummah NW yang cukup bagus sehingga tahapan ini dapat berjalan dengan lancer. Selain itu komitmen guru-guru untuk membimbing siswa-siswi dalam mengelola sampah khususnya dalam mnyimpan sampah sesuai jenisnya di tempat yang tepat.

\section{Produk Olahan Sampah dan Sayur Mayur}

Kegiatan pengabdian pada masyarakat yang dilaksanakan ini sangat dibatasi oleh waktu dan juga situasi bencana alam gempa bumi yang menimpa Pulau Lombok dan Sumbawa sejak bulan Juli-September 2018. Pada fase ini, belum dapat dihasilkan produk olahan sampah organis terutama pupuk organik. Pada kegiatan sebelumnya tahun 2017 yang dilakasankan secara sukarela dan terbatas oleh para remaja dan siswa telah dihasilkan pupuk organik. Kegiatan ini dilaksnakan pada instalasi sedehana lahan milik warga masyarakat (gambar 4). 

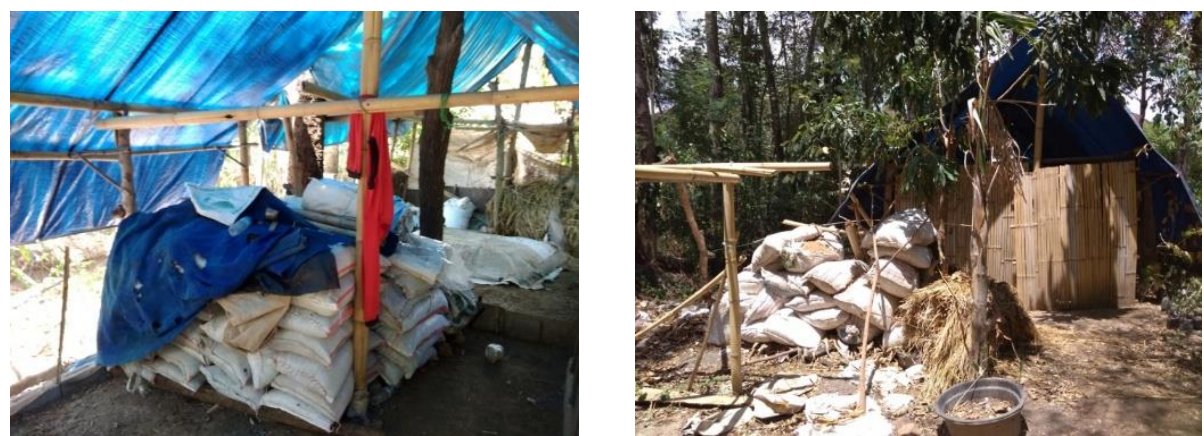

Gambar 4.

Instalasi pengelolaan pupuk organik dari kotoran hewan yang dibuat secara sukarela dan terbatas pada tahun 2017 oleh remaja Kelayu Jorong

Pupuk tersebut berbahan baku kotoran kambing. Kotoran kambing ini diperlakukakan secara aerobik dengan penambahan mikroorganisme untuk menghasilkan kompos (gambar 5)
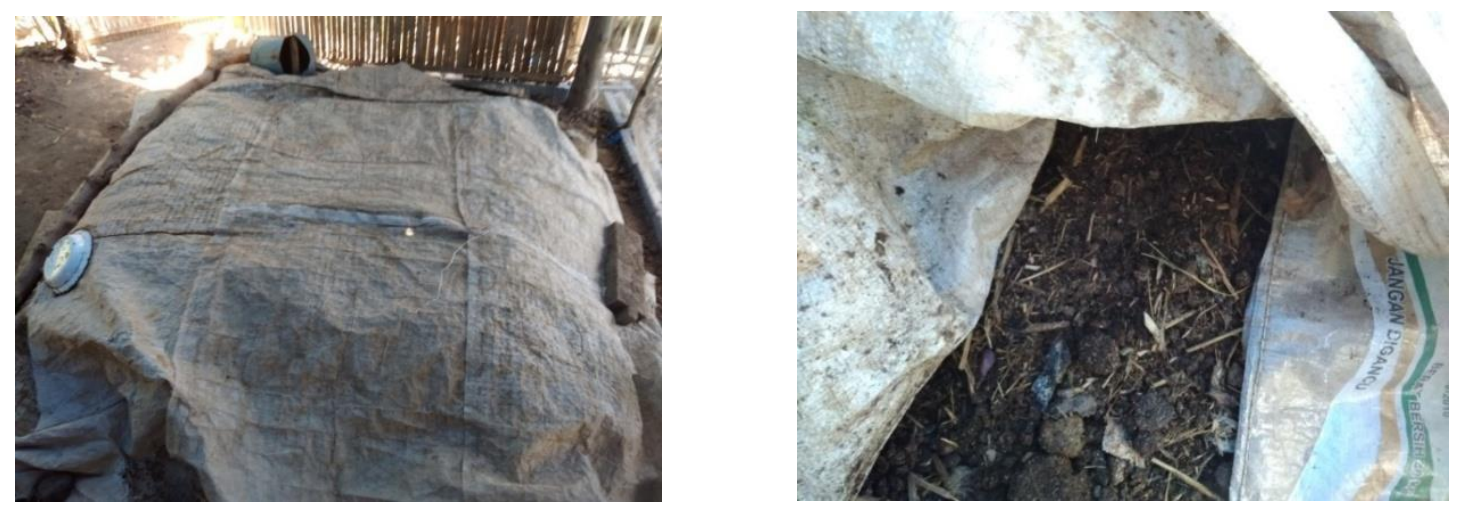

Gambar 5. Proses pengelolaan pupuk organik dari kotoran hewan yang dibuat secara sukarela dan terbatas pada tahun 2017 oleh remaja Kelayu Jorong
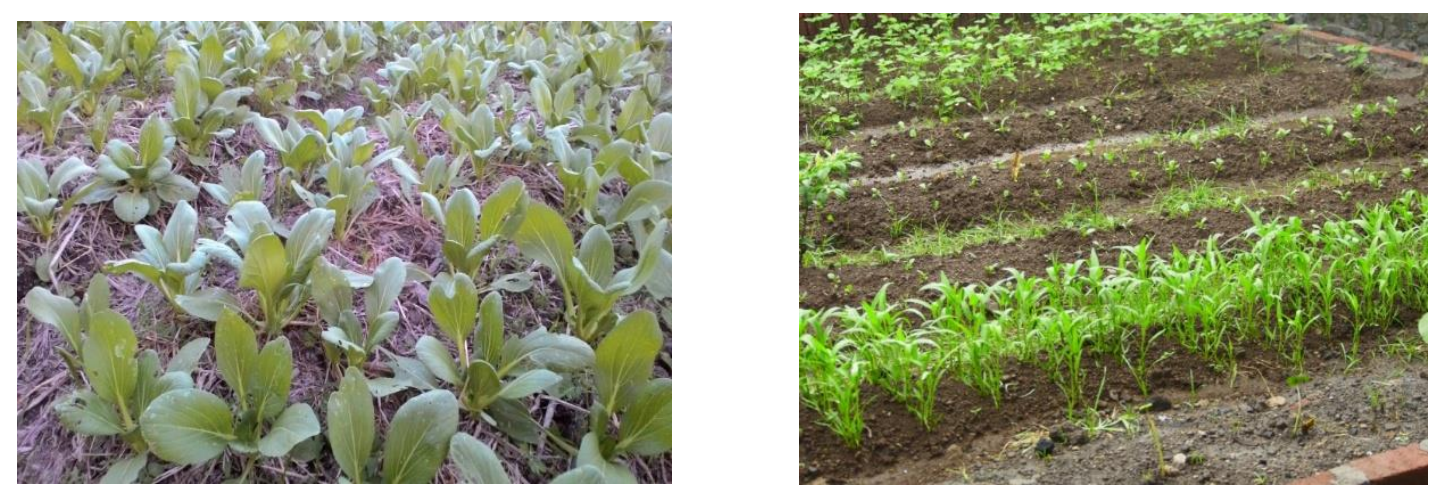

Gambar 6. Kangkung, Bayam, dan Pakcoy (sawi mangkok) yang ditanam di lahan dengan penambahan pupuk organic yang diproduksi oleh Remaja Kelayu Jorong 2017

Selain pupuk organik yang dihasilkan dari kotoran ternak di tas, pupuk tersebut juga diuji coba sebagai pupuk dan media tanam untuk pertanian organik. Hasil yang didapatkan selama proses uji coba tersebut cukup bagus. Pertumbuhan sayur sawi mangkok (Pakcoy), selada yang ditanam di 
lahan maupun di pot cukup bagus (gambar 6,7). Hasil pertanian tersebut juga dapat diterima di pasar lokal sekitar areal dan juga sekitar Kota Selong.
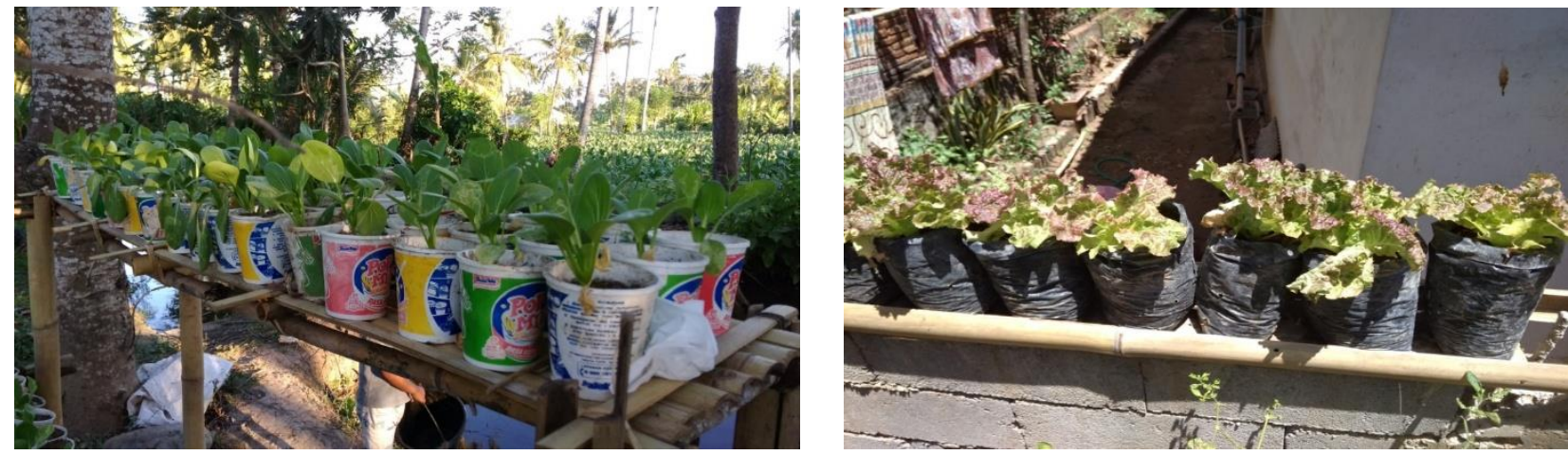

Gambar 6. Sayur pakcoy dan selada dengan media tanam pupuk organik dari kotoran hewan yang dibuat secara terbatas pada tahun 2017 oleh remaja Jorong

Kami berharap, kegiatan pegabdian masyarakat selanjutnya dapat memfasilitasi kelanjutan pengolahan sampah yang didapatkan dari sampah organik dari madrasah maupun dari masyarakat sekitar dan lahan pertanian yang ada. Mengingat

\section{KESIMPULAN}

Dalam kegiatan ini telah dilakukan pendekatan yaitu ceramah dan pemutaran audio visual tentang manajemen pengelolaan sampah yang meliputi pengetahuan jenis-jenis sampah, akibatakibat yang ditimbulkan oleh sampah, metode pembuangan sampah, serta pengolahan sederhana sampah menjadi produk yang bisa dimanfaatkan. Selain itu telah dilaksanakan demonstrasi yang meliputi desain penampung sampah berdasarkan jenisnya dan tata laksana pengumpulan sampah, serta pengolahan samapah sederhana menjadi produk yang bisa dimanfaatkan. Terbatasnya waktu serta kondisi lingkungan yang tidak memungkinkan akibat bencana alam gempa yang menimpa pulau Lombok akhir Juli-September 2018 menyebabkan tidak semua target kegiatan terpenuhi terutama pada fase pemanfaatan sampah organik dan uji coba penggunaaan produk pupuk organic untuk penanaman sayur organik.

\section{REFERENSI}

Badan Pusat Statistik(BPS). 2016. Kecamatan Dalam Angka. Badan Pusat Statistik

Kementerian Hukum dan HAM RI. 2008. Lembaran Negara RI No.68 tentang Undang-Undang No.18 Tahun 2008. Kementerian Hukum dan HAM RI, Jakarta

Suana IW, Ahyadi, H., Amir, S.2016. IbM Gili Matra dalam Upaya Pengelolaan Sampah Organik secara Terpadu. Laporan Pengabdian Kepada Masyarakat. Universitas Mataram

Yuniawati,M., Iskarima F., . 2012. Optimasi kondidi proses pembuatan kompos dari sampah organik dengan cara ferentasi menggunakan EM4. J.Teknologi 5(2):172-181 